\title{
SURFACE APPLICATION OF LIME AMELIORATES SUBSOIL ACIDITY AND IMPROVES ROOT GROWTH AND YIELD OF WHEAT IN AN ACID SOIL UNDER NO-TILL SYSTEM
}

\author{
Eduardo Fávero Caires ${ }^{1 *}$; José Cristovão Leal Corrêa ${ }^{2}$; Susana Churka ${ }^{2}$; Gabriel Barth ${ }^{3}$; \\ Fernando José Garbuio ${ }^{3}$ \\ ${ }^{1}$ UEPG - Depto. de Ciência do Solo e Engenharia Agrícola - Av. Gen. Carlos Cavalcanti, 4748 - 84030-900 - \\ Ponta Grossa, PR - Brasil. \\ ${ }^{2} U E P G$ - Programa de Pós-Graduação em Agronomia. \\ ${ }^{3}$ USP/ESALQ - Programa de Pós-Graduação em Solos e Nutrição de Plantas, C.P. 09 - 13418-900 - Piracicaba, \\ SP - Brasil. \\ *Corresponding author<efcaires@uepg.br>
}

\begin{abstract}
Crop root growth and grain yield can be affected by chemical modifications in the soil profile due to surface lime application. A field trial was carried out on a loamy dystrophic Typic Hapludox at Ponta Grossa, State of Paraná, Brazil, to evaluate root growth and grain yield of wheat (Triticum aestivum L. cv. CD 104, moderately susceptible to Al), about 10 years after surface liming ( 0 , 2, 4, and $6 \mathrm{Mg} \mathrm{ha}^{-1}$ ) and three years after surface re-liming ( 0 and $\left.3 \mathrm{Mg} \mathrm{ha}^{-1}\right)$, in a long-term no-till cultivation system. Soil acidity limited wheat root growth and yield severely, probably as a result of extended water deficits during the vegetative stage. Surface liming caused increases up to $66 \%$ in the root growth $(0-60 \mathrm{~cm})$ and up to $140 \%$ in the grain yield. Root density and grain yield were correlated positively with soil $\mathrm{pH}$ and exchangeable $\mathrm{Ca}^{2+}$, and negatively with exchangeable $\mathrm{Al}^{3+}$ and $\mathrm{Al}^{3+}$ saturation, in the surface and subsurface layers.
\end{abstract}

Key words: Triticum aestivum L., dolomitic lime, aluminum, calcium

\section{CALAGEM SUPERFICIAL EM SOLO ÁCIDO NO SISTEMA PLANTIO DIRETO MELHORA A ACIDEZ DO SUBSOLO E BENEFICIA O CRESCIMENTO RADICULAR E A PRODUÇÃO DE TRIGO}

\begin{abstract}
RESUMO: A calagem na superfície do solo em plantio direto ocasiona modificações químicas no perfil que podem influenciar o crescimento do sistema radicular e a produção de grãos das culturas. $\mathrm{O}$ crescimento de raízes e a produção de trigo (Triticum aestivum L. cv. CD 104, moderadamente sensível ao Al), foram estudados cerca de 10 anos após a aplicação superficial de calcário $\left(0,2,4\right.$ e $\left.6 \mathrm{Mg} \mathrm{ha}^{-1}\right)$ e três anos da reaplicação de calcário na superfície (0 e $\left.3 \mathrm{Mg} \mathrm{ha}^{-1}\right)$, em um Latossolo Vermelho distrófico textura média, manejado durante longo período no sistema plantio direto, em Ponta Grossa (PR). A acidez do solo limitou drasticamente o crescimento radicular e a produção de trigo, provavelmente por causa de prolongada falta de água ocorrida durante a fase de desenvolvimento vegetativo da cultura. A calagem na superfície ocasionou aumento de até $66 \%$ no crescimento radicular $(0-60 \mathrm{~cm})$ e de até $140 \%$ na produção de trigo. A densidade de raízes e a produção de trigo correlacionaram-se positivamente com o $\mathrm{pH}$ e o teor de $\mathrm{Ca}^{2+}$ trocável, e negativamente com o teor de $\mathrm{Al}^{3+}$ trocável e a saturação por $\mathrm{Al}^{3+}$, nas camadas superficiais e do subsolo.
\end{abstract}

Palavras-chave: Triticum aestivum L., calcário dolomítico, alumínio, cálcio

\section{INTRODUCTION}

Soil acidity frequently affects agricultural production in Brazil. The low content of calcium (Ritchey et al., 1982) and aluminum toxicity (Pavan et al., 1982) affect root growth and the absorption of water and nutrients by plants, usually causing reduction of crop yields in acid soils (Sumner et al., 1986).
Liming is the most efficient practice in order to solve problems related to soil acidity. To control soil acidity in a no-till (NT) system, lime is broadcast on the surface without incorporation. Since the lime reaction is generally limited to the layer it was applied, acidity at the subsurface layers, in case of toxic levels of aluminum and/or calcium deficiency, can compromise root penetration and plant nutrition. Results 
of field studies show that the movement of lime to depth varies according to timing and rates of liming, lime application forms, soil type, weather conditions, addition of acidic fertilizers, and cropping systems (Oliveira \& Pavan, 1996; Caires et al., 2000; Rheinheimer et al., 2000; Gascho \& Parker, 2001; Conyers et al., 2003; Pires et al., 2003; Tang et al., 2003).

No-till affects some chemical characteristics related to soil acidity that may influence plant development. Several experiments have attested no limitation to root growth (Caires et al., 2001; 2002a; 2002b; Tissi et al., 2004) and high crop yield (Pöttker \& Ben, 1998; Caires et al., 1999; Rheinheimer et al., 2000; Caires et al. 2002a; 2002b) in adverse acid soil conditions under NT.

Wheat is economically one of the most important winter crops in agricultural activities in South Brazil. Although there are genotypes with distinct reactions to soil acidity (Muzilli et al., 1978; Costa et al., 2003; Tang et al., 2002), there is a lack of information on the implications of soil acidity and surface liming on wheat root growth and grain yield under NT cultivation.

Root growth and grain yield of wheat were evaluated in an acid soil after surface application of lime rates and re-liming in a long-term NT cultivation system.

\section{MATERIAL AND METHODS}

The experiment was carried out in Ponta Grossa, PR, Brazil $\left(25^{\circ} 10^{\prime} \mathrm{S}, 50^{\circ} 05^{\prime} \mathrm{W}\right)$, on a dystrophic Typic Hapludox. At the beginning of the experiment, soil chemical and texture analyses of the 0-20 $\mathrm{cm}$ layer presented the following results: $\mathrm{pH}$ (1:2.5 soil: $0.01 \mathrm{~mol} \mathrm{~L}^{-1} \mathrm{CaCl}_{2}$ suspension) of 4.5 ; exchangeable $\mathrm{Al}^{3+}, \mathrm{Ca}^{2+}, \mathrm{Mg}^{2+}$, and $\mathrm{K}^{+}$contents of $6,16,10$, and 1.4 mmol $\mathrm{dm}^{-3}$, respectively; total acidity $\mathrm{pH} 7.0(\mathrm{H}+\mathrm{Al})$ of $58 \mathrm{mmol}_{\mathrm{c}}^{\mathrm{c}} \mathrm{dm}^{-3}$; P (Mehlich-1) of $9.0 \mathrm{mg} \mathrm{dm}{ }^{-3}$; total organic matter of $33 \mathrm{~g} \mathrm{dm}^{-3}$; base saturation of $32 \%$; $\mathrm{Al}^{3+}$ saturation of $18 \%$; and 295,240 , and $465 \mathrm{~g} \mathrm{~kg}^{-1}$ of clay, silt, and sand, respectively. Prior to the establishment of the experiment, the field site had been used for grain cropping under the NT cultivation system during 15 years.

A randomized complete block design was used, with three replications in a split-plot arrangement. The main plots $(8.0 \mathrm{~m} \times 6.3 \mathrm{~m})$ consisted of surface dolomitic lime at the rates of $0,2,4$, and 6 $\mathrm{Mg} \mathrm{ha}^{-1}$. The lime rates were calculated to raise the base saturation in the topsoil $(0-20 \mathrm{~cm})$ to 50,70 , and $90 \%$. The dolomitic lime used contained $176 \mathrm{~g} \mathrm{~kg}^{-1}$ $\mathrm{Ca}, 136 \mathrm{~g} \mathrm{~kg}^{-1} \mathrm{Mg}$, and $84 \%$ effective calcium car- bonate equivalent (ECCE), and was broadcast on the soil surface in July 1993. In June 2000, the main plots were divided in two subplots $(4.0 \mathrm{~m} \times 6.3 \mathrm{~m})$ for the study of surface re-liming influence $\left(196 \mathrm{~g} \mathrm{~kg}^{-1} \mathrm{Ca}\right.$, $130 \mathrm{~g} \mathrm{~kg}^{-1} \mathrm{Mg}$, and $90 \% \mathrm{ECCE}$ ) at the rates of 0 and $3 \mathrm{Mg} \mathrm{ha}^{-1}$. The reapplied rate was calculated to raise the base saturation in the topsoil $(0-20 \mathrm{~cm})$ to $65 \%$ (Caires et al., 2000) of the treatment $4 \mathrm{Mg} \mathrm{ha}^{-1}$ of lime made in July 1993 (pH $0.01 \mathrm{~mol} \mathrm{~L}^{-1} \mathrm{CaCl}_{2}$ of 4.6; CEC $\mathrm{pH} 7.0$ of $110.8 \mathrm{mmol}_{\mathrm{c}} \mathrm{dm}^{-3}$; and $41 \%$ of base saturation).

The crop succession was the following: soybean (1993-1994), black oat mixed with common vetch (1994), corn (1994-1995), fallow (1995), soybean (1995-1996), wheat (1996), soybean (19961997), triticale (1997), soybean (1997-1998), black oat (1998), soybean (1998-1999), black oat (1999), soybean (1999-2000), black oat (2000), corn (20002001), black oat (2001), soybean (2001-2002), black oat (2002), soybean (2002-2003), and wheat (2003). The present work addresses only the last wheat crop, since the root growth and grain yield of this crop were studied more thoroughly.

Wheat, cv. CD 104 (moderately susceptible to the soil exchangeable aluminum, with tolerance to $\mathrm{Al}^{3+}$ saturation between 5 and $20 \%$ at the $0-20 \mathrm{~cm}$ depth, according to IAPAR, 2003) was sown on June 14, 2003 , with $0.17 \mathrm{~m}$ between rows and $140 \mathrm{~kg}$ of seed per hectare, for a population between 250 and 300 plants $\mathrm{m}^{-2}$. During wheat sowing no fertilizer was applied due to the residual effect of the fertilizer applied $\left(24 \mathrm{~kg} \mathrm{ha}^{-1} \mathrm{P}\right.$ and $46 \mathrm{~kg} \mathrm{ha}^{-1} \mathrm{~K}$ ) to the prior crop (soybean). The plants emerged on June 21, 2003 and were counted on June 28,2003 . The initial average population was 255 plants $\mathrm{m}^{-2}$, without effect of the liming treatments. Fertilizers were applied by top dressing (August, 05, 2003) at rates of $80 \mathrm{~kg} \mathrm{ha}^{-1} \mathrm{~N}$ and $35 \mathrm{~kg}$ $\mathrm{ha}^{-1} \mathrm{~K}$, as ammonium nitrate and potassium chloride, respectively.

Wheat plants flowered fully in September 13, 2003, 84 days after emergence, and the crop maturation occurred in October 25, 2003, 126 days after emerging.

The air temperature was adequate for the wheat to develop and there was considerable rainfall before sowing $(55 \mathrm{~mm})$ and before the plant flowering (56 $\mathrm{mm})$. However, there was an extended water deficit during the vegetative development stage (Figure 1). Rainfall was $434 \mathrm{~mm}$ during the wheat crop cycle.

Samples of wheat roots were collected during the flowering period, in September 20, 2003, by means of a sampling tube of $3.5 \mathrm{~cm}$ diameter, at the depths of 0-10, 10-20, and 20-60 cm. Six sub-samples (3 from the sowing row and 3 between rows) were taken 


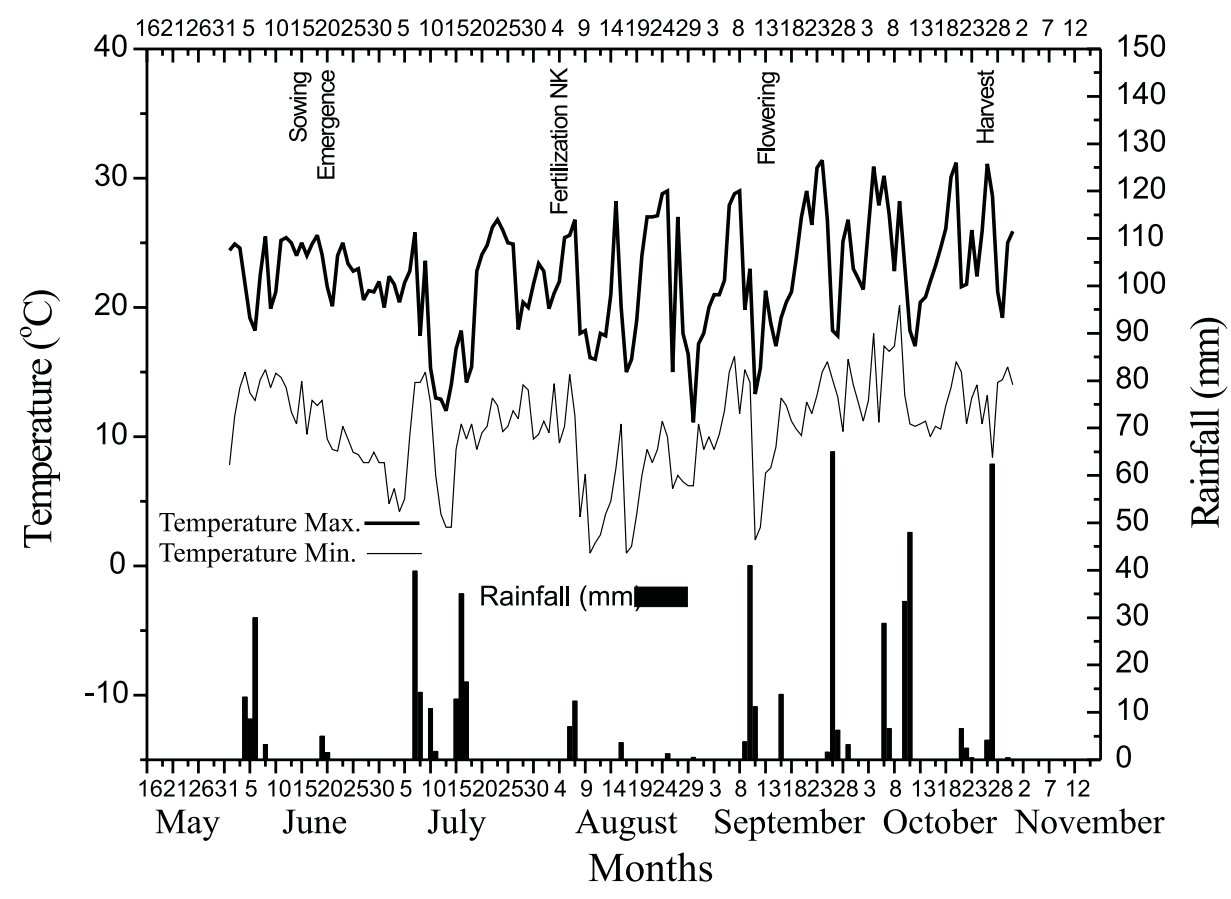

Figure 1 - Maximum and minimum air temperature and rainfall throughout the development period of the wheat crop in 2003.

randomly in the sub-plot to form a composite sample. The roots were separated from the soil by dispersion in water through a $0.5 \mathrm{~mm}$ mesh sieve. Root length was estimated by the method of Tennant (1975), in a $1 \times 1 \mathrm{~cm}$ grid. The average root radius was calculated by the following equation (Schenk \& Barber, 1979): $r=\left(m u \pi L^{-1}\right)^{1 / 2}$, where mu is the wet mass and $\mathrm{L}$, the root length.

After maturation, the wheat grain was harvested from $6.12 \mathrm{~m}^{2}$ plots (middle 12 rows by $3 \mathrm{~m}$ in length). Grain was processed in screen for the amount of middling to be removed and measured for each subplot. The values of wheat middling obtained and its proportion to the production were used in the treatment evaluation. Grain yield was expressed at the $130 \mathrm{~g} \mathrm{~kg}^{-1}$ moisture content.

The results were submitted to variance and polynomial regression analyses. Regression equations were adjusted to the obtained data according to lime rates, adopting as criteria for the model choice the agronomic meaning and the magnitude of coefficients of determination significant at $5 \%$. The effects of re-liming were compared through the F-test.

\section{RESULTS AND DISCUSSION}

Liming treatments caused varied soil acidity conditions for plant development, as intended (Table 1). Soil chemical analyses performed according to the methods recommended by Pavan et al. (1992), before sowing wheat, revealed increases of $\mathrm{pH}$, exchangeable
$\mathrm{Ca}^{2+}$ and $\mathrm{Mg}^{2+}$, and base saturation, and also the reduction of exchangeable $\mathrm{Al}^{3+}$ and $\mathrm{Al}^{3+}$ saturation, in the surface and subsurface layers, with surface liming. Considering the rates and the re-liming, soil $\mathrm{pH} 0.01$ mol L-1 $\mathrm{CaCl}_{2}$ varied from 4.4 to 6.1 , in the $0-5 \mathrm{~cm}$ layer, from 4.2 to 5.3 , in the $5-10 \mathrm{~cm}$ layer, and from 4.2 to 4.8 , from 10 to $60 \mathrm{~cm}$ depth; the exchangeable $\mathrm{Al}^{3+}$ varied from 0 to $7 \mathrm{mmol}_{\mathrm{c}} \mathrm{dm}^{-3}$, from 0 to 11 mmol $\mathrm{dm}^{-3}$, and from 2 to $10 \mathrm{mmol}_{\mathrm{c}} \mathrm{dm}^{-3}$, respectively in at depths of $0-5,5-10$, and $10-60 \mathrm{~cm}$; and the variation in the $\mathrm{Al}^{3+}$ saturation was from 0 to $20 \%$ (0$5 \mathrm{~cm})$, from 0 to $34 \%(5-10 \mathrm{~cm})$, and from 5 to $35 \%$ $(10-60 \mathrm{~cm})$.

The traits of wheat root growth were not significantly influenced by the interaction between lime rates and re-liming. So, the results regarding the growth of the root system were analyzed separately by the means of the observations.

The length density of wheat roots $(\hat{y}$, in $\mathrm{cm}$ $\mathrm{cm}^{-3}$ ) increased linearly according to the surface-applied lime rates $\left(x\right.$, in $\left.\mathrm{Mg} \mathrm{ha}^{-1}\right)$, at depths of $0-10 \mathrm{~cm}$ $\left(\hat{y}=5.65+0.534 x, \mathrm{R}^{2}=0.91\right), 10-20 \mathrm{~cm}(\hat{y}=0.91$ $\left.+0.122 x, \mathrm{R}^{2}=0.94\right)$, and $20-60 \mathrm{~cm}(\hat{y}=0.57+$ $\left.0.047 x, \mathrm{R}^{2}=0.81\right)$. Surface re-liming also increased the length density of wheat roots at depths of $0-10$, 10-20, and 20-60 cm (Table 2).

The mean radius of wheat roots $(\hat{y}$, in $\mathrm{mm})$ decreased linearly with increasing surface liming rate $\left(x\right.$, in $\left.\mathrm{Mg} \mathrm{ha}{ }^{-1}\right)$, at depths of $0-10 \mathrm{~cm}(\hat{y}=0.13-$ $\left.0.002 x, \mathrm{R}^{2}=0.98\right)$ and $10-20 \mathrm{~cm}(\hat{y}=0.14-0.004 x$, $\left.\mathrm{R}^{2}=0.87\right)$, but surface re-liming did not cause sig- 
Table 1 - Soil chemical attributes for different depths before sowing wheat, about $10 \mathrm{yr}$ after surface liming application and $3 \mathrm{yr}$ after surface re-liming at the rate of $3 \mathrm{Mg} \mathrm{ha}^{-1}$.

\begin{tabular}{|c|c|c|c|c|c|c|c|c|c|c|}
\hline \multirow{2}{*}{ Depth } & \multirow{2}{*}{ Lime } & \multirow{2}{*}{$\mathrm{pH}\left(\mathrm{CaCl}_{2}\right)$} & \multirow{2}{*}{$\mathrm{H}^{+}+\mathrm{Al}^{3+}$} & \multicolumn{4}{|c|}{ Exchangeable Cations } & \multirow{2}{*}{ P Mehlich-1 } & \multirow{2}{*}{$\mathrm{Al}^{\beta^{+}}$Saturation } & \multirow{2}{*}{ BaseSaturatior } \\
\hline & & & & $\mathrm{Al}^{3+}$ & $\mathrm{Ca}^{2+}$ & $\mathrm{Mg}^{2+}$ & $\mathrm{K}^{+}$ & & & \\
\hline $\mathrm{cm}$ & $\mathrm{Mg} \mathrm{ha}^{-1}$ & & \multicolumn{5}{|c|}{ mmolc $\mathrm{dm}^{-3}-\ldots$} & $\mathrm{mg} \mathrm{dm} \mathrm{m}^{-3}$ & \multicolumn{2}{|c|}{ - } \\
\hline \multicolumn{11}{|c|}{ Without re-liming } \\
\hline \multirow[t]{5}{*}{$0-5$} & 0 & 4.4 & 80 & 7 & 15 & 11 & 2.6 & 10.3 & 20 & 26 \\
\hline & 2 & 4.8 & 56 & 2 & 31 & 18 & 2.8 & 8.8 & 4 & 48 \\
\hline & 4 & 5.0 & 55 & 0 & 32 & 22 & 2.3 & 8.8 & 0 & 51 \\
\hline & 6 & 5.3 & 46 & 0 & 37 & 27 & 2.5 & 10.7 & 0 & 59 \\
\hline & Effect & $\mathrm{L}^{* *}$ & $L^{*}$ & $\mathrm{~L}^{*}$ & $\mathrm{~L}^{* *}$ & $\mathrm{~L}^{*}$ & ns & ns & $\mathrm{L}^{*}$ & $\mathrm{~L}^{* *}$ \\
\hline \multirow[t]{5}{*}{$5-10$} & 0 & 4.2 & 86 & 11 & 10 & 10 & 1.5 & 8.2 & 34 & 20 \\
\hline & 2 & 4.5 & 74 & 5 & 19 & 16 & 1.2 & 6.3 & 12 & 33 \\
\hline & 4 & 4.8 & 60 & 3 & 27 & 18 & 1.8 & 7.5 & 6 & 44 \\
\hline & 6 & 4.9 & 57 & 1 & 27 & 18 & 1.0 & 7.3 & 2 & 45 \\
\hline & Effect & $\mathrm{L}^{* *}$ & $\mathrm{~L}^{* *}$ & $\mathrm{~L}^{* *}$ & $\mathrm{~L}^{*}$ & $\mathrm{~L}^{*}$ & ns & ns & $\mathrm{L}^{* *}$ & $\mathrm{~L}^{* *}$ \\
\hline \multirow[t]{5}{*}{$10-20$} & 0 & 4.2 & 80 & 10 & 8 & 9 & 1.2 & 3.1 & 35 & 19 \\
\hline & 2 & 4.5 & 72 & 6 & 15 & 11 & 1.0 & 2.6 & 18 & 27 \\
\hline & 4 & 4.5 & 67 & 5 & 15 & 13 & 1.0 & 3.1 & 15 & 30 \\
\hline & 6 & 4.6 & 63 & 3 & 17 & 14 & 0.8 & 3.6 & 9 & 34 \\
\hline & Effect & $L^{* *}$ & $L^{* *}$ & $L^{* *}$ & $\mathrm{~L}^{*}$ & $\mathrm{~L}^{*}$ & ns & ns & $\mathrm{L}^{* *}$ & $L^{* *}$ \\
\hline \multirow{5}{*}{ 20-60 } & 0 & 4.3 & 70 & 8 & 7 & 7 & 0.8 & 1.7 & 35 & 17 \\
\hline & 2 & 4.5 & 64 & 5 & 11 & 11 & 0.5 & 1.4 & 22 & 26 \\
\hline & 4 & 4.6 & 61 & 4 & 12 & 12 & 0.6 & 1.4 & 14 & 29 \\
\hline & 6 & 4.6 & 55 & 3 & 13 & 13 & 0.5 & 2.0 & 10 & 33 \\
\hline & Effect & $\mathrm{L}^{* *}$ & $\mathrm{~L}^{* *}$ & $\mathrm{~L}^{* *}$ & $\mathrm{~L}^{*}$ & ns & ns & ns & $\mathrm{L}^{* *}$ & $\mathrm{~L}^{* *}$ \\
\hline \multicolumn{11}{|c|}{ With re-liming at $3 \mathrm{Mg} \mathrm{ha}^{-1}$} \\
\hline \multirow[t]{5}{*}{$0-5$} & 0 & 5.3 & 48 & 0 & 34 & 25 & 2.6 & 9.3 & 0 & 56 \\
\hline & 2 & 5.6 & 44 & 0 & 42 & 29 & 2.6 & 9.2 & 0 & 63 \\
\hline & 4 & 5.7 & 38 & 0 & 47 & 27 & 2.8 & 14.7 & 0 & 67 \\
\hline & 6 & 6.1 & 29 & 0 & 49 & 29 & 2.3 & 12.2 & 0 & 73 \\
\hline & Effect & $\mathrm{L}^{* *}$ & $\mathrm{~L}^{* *}$ & ns & $\mathrm{L}^{*}$ & ns & ns & $L^{*}$ & ns & $\mathrm{L}^{* *}$ \\
\hline \multirow[t]{5}{*}{$5-10$} & 0 & 4.4 & 74 & 8 & 13 & 15 & 1.1 & 9.0 & 22 & 28 \\
\hline & 2 & 4.6 & 69 & 4 & 20 & 22 & 1.1 & 7.7 & 8 & 38 \\
\hline & 4 & 4.8 & 61 & 2 & 23 & 21 & 1.1 & 7.9 & 4 & 43 \\
\hline & 6 & 5.3 & 47 & 0 & 28 & 23 & 0.9 & 13.6 & 0 & 52 \\
\hline & Effect & $\mathrm{L}^{* *}$ & $\mathrm{~L}^{* *}$ & $\mathrm{~L}^{* *}$ & $\mathrm{~L}^{*}$ & $\mathrm{~L}^{*}$ & ns & ns & $\mathrm{L}^{* *}$ & $\mathrm{~L}^{* *}$ \\
\hline \multirow[t]{5}{*}{$10-20$} & 0 & 4.4 & 71 & 7 & 10 & 12 & 0.9 & 3.0 & 23 & 24 \\
\hline & 2 & 4.5 & 70 & 5 & 14 & 15 & 0.9 & 3.0 & 14 & 30 \\
\hline & 4 & 4.6 & 69 & 5 & 14 & 14 & 0.9 & 3.0 & 15 & 30 \\
\hline & 6 & 4.8 & 56 & 2 & 21 & 16 & 0.7 & 3.9 & 5 & 40 \\
\hline & Effect & $\mathrm{L}^{* *}$ & $\mathrm{~L}^{*}$ & $\mathrm{~L}^{*}$ & $\mathrm{~L}^{*}$ & ns & ns & ns & $\mathrm{L}^{* *}$ & $\mathrm{~L}^{*}$ \\
\hline \multirow[t]{5}{*}{ 20-60 } & 0 & 4.5 & 64 & 6 & 11 & 9 & 0.7 & 1.4 & 22 & 24 \\
\hline & 2 & 4.6 & 63 & 4 & 12 & 13 & 0.6 & 1.4 & 14 & 29 \\
\hline & 4 & 4.6 & 60 & 4 & 15 & 11 & 0.5 & 1.4 & 13 & 31 \\
\hline & 6 & 4.8 & 53 & 2 & 17 & 15 & 0.6 & 2.0 & 6 & 38 \\
\hline & Effect & $L^{* *}$ & $L^{*}$ & $\mathrm{~L}^{*}$ & $\mathrm{~L}^{*}$ & ns & ns & ns & $L^{* *}$ & $L^{*}$ \\
\hline
\end{tabular}

L: Linear effect by polynomial regression, ns: non-significant, *: significant at $P<0.05$, and **: significant at $P<0.01$. 
nificant alterations in the mean root radius (Table 2). The mean root radius was greater (thicker roots) in conditions of more acid soil, with larger concentrations of exchangeable $\mathrm{Al}^{3+}$ (Table 1).

Increasing surface liming rate $\left(x\right.$, in $\left.\mathrm{Mg} \mathrm{ha}^{-1}\right)$ increased linearly wheat root length per unit surface area $\left(\hat{y}\right.$, in $\left.\mathrm{cm} \mathrm{cm}^{-2}\right)$ to the depth of $60 \mathrm{~cm}(\hat{y}=88.36$ $\left.+8.46 x, \mathrm{R}^{2}=0.92\right)$. Re-liming also increased significantly the root length of wheat to the depth of $60 \mathrm{~cm}$
(Table 3). The increase in the root length with liming was up to $66 \%$. However, the relative wheat root length in the soil profile was not affected by surface liming. There was higher concentration of the wheat root length at $0-10 \mathrm{~cm}$ depth (62-66\%), independently of liming. The relative length of wheat roots was about $75 \%$ at the $0-20 \mathrm{~cm}$ depth, which agrees with results of other studies (Rosolem et al., 1992; Caires et al., 2002a, Tang et al., 2002; 2003).

Table 2 - Wheat root length density and mean radius as affected by surface liming application and surface re-liming at the rate of $3 \mathrm{Mg} \mathrm{ha}^{-1}$.

\begin{tabular}{|c|c|c|c|c|c|c|}
\hline \multirow{2}{*}{ Treatment } & \multicolumn{3}{|c|}{ Root length density } & \multicolumn{3}{|c|}{ Root mean radius } \\
\hline & $0-10 \mathrm{~cm}$ & $10-20 \mathrm{~cm}$ & $20-60 \mathrm{~cm}$ & $0-10 \mathrm{~cm}$ & $10-20 \mathrm{~cm}$ & $20-60 \mathrm{~cm}$ \\
\hline & - n & $-\mathrm{cm} \mathrm{cm}^{-3}-$ & - & - & -.-- mm -.. & (n) \\
\hline \multicolumn{7}{|l|}{ Lime, $\mathrm{Mg}$ ha $^{-1}$} \\
\hline 0 & 5.2 & 0.9 & 0.5 & 0.13 & 0.15 & 0.12 \\
\hline 2 & 7.3 & 1.3 & 0.7 & 0.12 & 0.13 & 0.12 \\
\hline 4 & 7.9 & 1.3 & 0.7 & 0.12 & 0.13 & 0.11 \\
\hline 6 & 8.6 & 1.7 & 0.9 & 0.12 & 0.12 & 0.11 \\
\hline Effect & $\mathrm{L}^{* *}$ & $\mathrm{~L}^{* *}$ & $\mathrm{~L}^{*}$ & $\mathrm{~L}^{* *}$ & $\mathrm{~L}^{* *}$ & ns \\
\hline CV (\%) & 18.0 & 27.8 & 26.9 & 5.8 & 8.7 & 7.7 \\
\hline \multicolumn{7}{|l|}{ Reapplication of lime } \\
\hline Without re-liming & 6.7 & 1.1 & 0.6 & 0.12 & 0.13 & 0.11 \\
\hline With re-liming at $3 \mathrm{Mg} \mathrm{ha}^{-1}$ & 7.9 & 1.5 & 0.8 & 0.12 & 0.13 & 0.11 \\
\hline F Value & $5.9 *$ & $12.7 * *$ & $6.4^{*}$ & $0.0 \mathrm{~ns}$ & $0.9 \mathrm{~ns}$ & $0.3 \mathrm{~ns}$ \\
\hline CV (\%) & 16.5 & 19.7 & 30.7 & 2.9 & 10.5 & 7.1 \\
\hline
\end{tabular}

L: Linear effect by polynomial regression, ns: non-significant, *: significant at $P<0.05$, and **: significant at $P<0.01$.

Table 3 - Total root length per unit surface area in the 0-60 cm layer, and relative root length of wheat in various layers as affected by surface liming application and surface re-liming at the rate of $3 \mathrm{Mg} \mathrm{ha}^{-1}$.

\begin{tabular}{|c|c|c|c|c|}
\hline \multirow{2}{*}{ Treatment } & \multirow{2}{*}{$\begin{array}{c}\text { Root length per unit } \\
\text { surface area }(0-60 \mathrm{~cm})\end{array}$} & \multicolumn{3}{|c|}{ Relative root length } \\
\hline & & $0-10 \mathrm{~cm}$ & $10-20 \mathrm{~cm}$ & $20-60 \mathrm{~cm}$ \\
\hline & $\mathrm{cm} \mathrm{cm}^{-2}$ & - - - & - \% - - - & - \\
\hline \multicolumn{5}{|l|}{ Lime, $\mathrm{Mg} \mathrm{ha}^{-1}$} \\
\hline 0 & 82.8 & 64 & 11 & 25 \\
\hline 2 & 114.7 & 64 & 11 & 25 \\
\hline 4 & 120.1 & 66 & 11 & 23 \\
\hline 6 & 137.3 & 63 & 12 & 25 \\
\hline Effect & $\mathrm{L}^{* *}$ & ns & $\mathrm{ns}$ & ns \\
\hline CV $(\%)$ & 17.8 & 6.9 & 6.1 & 17.5 \\
\hline \multicolumn{5}{|l|}{ Reapplication of lime } \\
\hline Without re-liming & 101.4 & 62 & 11 & 23 \\
\hline With re-liming at $3 \mathrm{Mg} \mathrm{ha}^{-1}$ & 126.0 & 66 & 12 & 26 \\
\hline F Value & $9.7 *$ & $4.1 \mathrm{~ns}$ & $0.1 \mathrm{~ns}$ & $3.1 \mathrm{~ns}$ \\
\hline $\mathrm{CV}(\%)$ & 17.0 & 6.4 & 22.8 & 17.7 \\
\hline
\end{tabular}

L: Linear effect by polynomial regression, ns: non-significant, *: significant at $P<0.05$, and **: significant at $P<0.01$. Relative root length $=($ root length at $0-10,10-20$, or $20-60 \mathrm{~cm}$ depth/total root length to the depth of $60 \mathrm{~cm}) \times 100$. 
The correlation analysis between the traits of wheat root growth and the soil chemical attributes (Table 4) shows that the root growth was favored mainly by the increase of $\mathrm{pH}$, exchangeable $\mathrm{Ca}^{2+}$ and base saturation, and by the reduction of exchangeable $\mathrm{Al}^{3+}$ and $\mathrm{Al}^{3+}$ saturation in the soil, due to surface liming (Table 1). The exchangeable $\mathrm{Al}^{3+}$ and the $\mathrm{Al}^{3+}$ saturation were the soil attributes that presented the closest correlations with the root growth per unit surface area to the depth of $60 \mathrm{~cm}$, showing that there was aluminum toxicity for wheat root growth. The aluminum in toxic concentrations causes reduction in root growth rate, but the reaction of genotypes to the aluminum in acid soils is variable (Muzilli et al., 1978; Costa et al., 2003; Tang et al., 2002; 2003). These results differ substantially from those obtained for soybean (Caires et al., 2001) and corn (Caires et al., 2002b; Tissi et al., 2004), in similar conditions of soil acidity under NT. In these studies, concentrations of exchangeable $\mathrm{Al}^{3+}$ in the soil from 8 to $11 \mathrm{mmol}_{\mathrm{c}} \mathrm{dm}^{-3}$ did not cause limitation to root growth for corn and soybean, both cultivated in the absence of water deficit under NT. Although plant genotypes differ in their susceptibility to soil acidity, Muzilli et al. (1978) observed practically that wheat cultivars were twice more tolerant to soil acidity ( $\mathrm{Al}^{3+}$ saturation) than the soybean cultivars.

Studies have shown smaller toxicity of aluminum in systems in which crop residues are left on the soil surface (Miyazawa et al., 1993; Franchini et al., 1999; Salet et al., 1999). The higher content of organic matter (Bayer et al., 2000; Rhoton, 2000) and the greater nutrient concentration on the soil surface (Rhoton, 2000) under NT may reduce aluminum toxicity through the formation of Al-organic complexes and the greater ionic strength of the soil solution (Salet et al., 1999). However, this low toxicity of alu- minum for root growth of plants under NT (Caires et al., 2001; 2002b; Tissi et al., 2004) should only occur in the absence of water deficit. In this study, although the rain episodes occurred in adequate intensity soon after sowing and at the beginning of wheat flowering, rainfall was irregular during the crop cycle - long periods with water limitation were observed during the vegetative development stage (Figure 1). The aluminum phytotoxicity under NT seems to be quite dependent on the water regime occurring during the growth cycle of the plants in the field. In unfavorable conditions of rainfall, the phytotoxicity of $\mathrm{Al}^{3+}$ due to high soil acidity is intensified and compromises severely root growth of plants with little tolerance to aluminum.

Wheat grain yield and middling proportion were significantly influenced by the interaction between lime rates and re-liming (Figure 2). Grain yield of wheat increased linearly with the application of lime on the soil surface, with or without surface reliming (Figure 2a). Re-liming increased grain yield of wheat only for the smaller rates of lime $(0$ and $2 \mathrm{Mg}$ $\mathrm{ha}^{-1}$ ), when the soil presented higher acidity (Table 1). According to the adjusted regression equations, the increases in grain yields were 380 and $200 \mathrm{~kg} \mathrm{ha}^{-1}$ per $\mathrm{Mg}$ of lime, corresponding to a yield increase of $130 \%$ and $40 \%$ with the highest lime rate applied (6 $\mathrm{Mg} \mathrm{ha} \mathrm{a}^{-1}$ ), respectively without and with re-liming. Re-liming at the rate of $3 \mathrm{Mg} \mathrm{ha}^{-1}$, on plots that had not received prior liming, increased wheat grain yield by $72 \%$. Wheat grain yield was $140 \%$ higher in the treatment that received $6+3 \mathrm{Mg} \mathrm{ha}^{-1}$ of lime than in the control treatment without liming. Surface application of lime rates reduced wheat middling proportion only in the absence of re-liming (Figure 2b). Reliming at the rate of $3 \mathrm{Mg} \mathrm{ha}^{-1}$ also reduced wheat middling proportion but only in the absence of prior

Table 4 - Coefficients of correlation between wheat root growth traits and soil chemical attributes for different soil layers.

\begin{tabular}{|c|c|c|c|c|c|c|}
\hline Depth & $\mathrm{pH}\left(\mathrm{CaCl}_{2}\right)$ & Exchangeable $\mathrm{Al}^{3+}$ & $\mathrm{Al}^{3+}$ saturation & Exchangeable $\mathrm{Ca}^{2+}$ & Exchangeable $\mathrm{Mg}^{2+}$ & Base saturation \\
\hline \multicolumn{7}{|l|}{$\mathrm{cm}$} \\
\hline & \multicolumn{6}{|c|}{ Root Length Density } \\
\hline $0-10$ & $0.69 * *$ & $-0.75 * *$ & $-0.75 * *$ & $0.80 * *$ & $0.43 *$ & $0.70 * *$ \\
\hline $10-20$ & $0.76 * *$ & $-0.67 * *$ & $-0.64 * *$ & $0.74 * *$ & $-0.01 \mathrm{~ns}$ & $0.59 * *$ \\
\hline \multirow[t]{2}{*}{$20-60$} & $0.69 * *$ & $-0.72 * *$ & $-0.73 * *$ & $0.47 *$ & $-0.43^{*}$ & $0.60 * *$ \\
\hline & \multicolumn{6}{|c|}{ Root Mean Radius } \\
\hline $0-10$ & $-0.52 * *$ & $0.55^{* *}$ & $0.55 * *$ & $-0.48 *$ & $-0.44 *$ & $-0.56 * *$ \\
\hline $10-20$ & $-0.60 * *$ & $0.67 * *$ & $0.73 * *$ & $-0.47^{*}$ & $-0.56 * *$ & $-0.75 * *$ \\
\hline \multirow[t]{2}{*}{$20-60$} & $-0.30 \mathrm{~ns}$ & $0.13 \mathrm{~ns}$ & $0.15 \mathrm{~ns}$ & $-0.01 \mathrm{~ns}$ & $-0.13 n s$ & $-0.15 \mathrm{~ns}$ \\
\hline & \multicolumn{6}{|c|}{ Root Length per Unit Surface Area } \\
\hline $0-60$ & $0.79 * *$ & $-0.85 * *$ & $-0.83 * *$ & $0.73 * *$ & $0.40 *$ & $0.72 * *$ \\
\hline
\end{tabular}

ns: non-significant, *: significant at $P<0.05$, and **: significant at $P<0.01$. 
liming, under more acid soil conditions. These results showed, unquestionably, that surface application of lime to control soil acidity under NT increased yield and quality of wheat grain.

The increase in wheat grain yield with surface liming was related significantly with the increase of soil $\mathrm{pH}$, exchangeable $\mathrm{Ca}^{2+}$ and base saturation, and with the reduction of exchangeable $\mathrm{Al}^{3+}$ and $\mathrm{Al}^{3+}$ saturation, at the four studied depths (Table 5). Wheat response to liming soils was observed where the $\mathrm{Al}^{3+}$ saturation was more than $25 \%$ (Winkler \& Sfredo, 1991). In another trial using a range of wheat genotypes, the increase in wheat grain yield was also related to the reduction in soil aluminum saturation (Costa et al., 2003). Therefore, the improvement in soil acidity conditions at the surface and in subsurface layers by surface liming application under NT had positive effects on wheat grain yield.

A series of studies have shown high wheat, corn and soybean grain yields in acid soils under NT and little response of these crops to surface liming (Pöttker \& Ben, 1998; Caires et al., 1999; Rheinheimer et al., 2000; Caires et al., 2002a; 2002b). The explanations for this behavior has been related

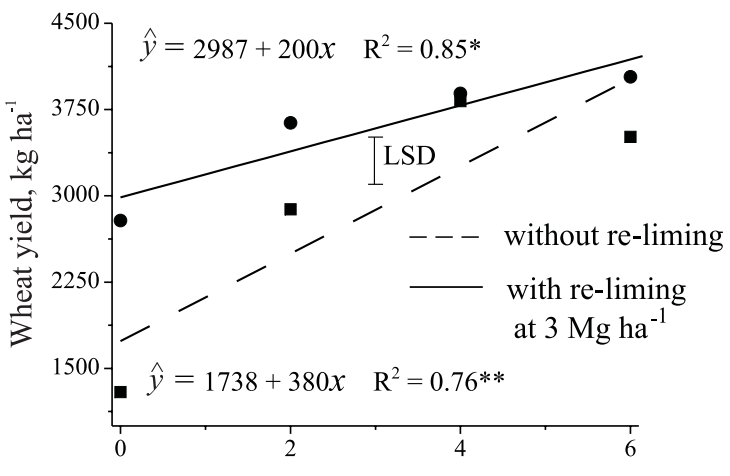

a)

Lime, $\mathrm{Mg} \mathrm{ha}^{-1}$ to the following inherent factors to this cropping system: (i) $\mathrm{pH}$ increase and reduction of the $\mathrm{Al}^{3+}$ content by water soluble organic compounds from vegetable materials that are left on the soil surface to serve as a mulch; (ii) reduction of the $\mathrm{Al}^{3+}$ activity in solution due to the higher organic matter content and the higher nutrient concentration in the soil surface, and (iii) sufficient exchangeable cation concentrations, even in soils of high acidity, due to the increase in the cation exchange capacity because of the higher content of organic matter. However, these data were obtained of field experiments performed without the occurrence of water limitation. In this study, there was marked response of wheat to surface liming, probably due to an increased concentration of $\mathrm{Al}^{3+}$ in soil solution as a result of extended water deficit during the vegetative development stage, showing that the response of the crops to liming under NT seems to depend on the water regime that occurs during the growing cycle of the plants.

\section{ACKNOWLEDGEMENTS}

To CNPq and to CAPES for providing scholarships to the authors.

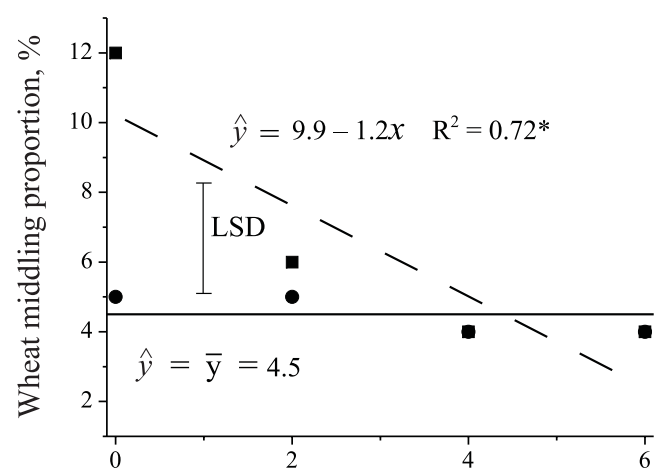

b)

Figure 2 - Wheat grain yield (a) and middling proportion (b) as affected by surface liming application, without (ロ) and with (•) surface re-liming at the rate of $3 \mathrm{Mg} \mathrm{ha}^{-1}$. Wheat middling proportion $=$ (amount of middling/total grain production $) \times 100$. Bars represent the least significant difference (LSD) by Tukey test at $P=0.05$. *: significant at $P<0.05$ and **:significant at $P<0.01$.

Table 5 - Coefficients of correlation between wheat grain yield and soil chemical attributes for different soil layers.

\begin{tabular}{lcccccc}
\hline Depth & $\mathrm{pH}\left(\mathrm{CaCl}_{2}\right)$ & Exchangeable $\mathrm{Al}^{3+}$ & $\mathrm{Al}^{3+}$ saturation & Exchangeable $\mathrm{Ca}^{2+}$ & ${\text { Exchangeable } \mathrm{Mg}^{2+}}^{\mathrm{Base}^{2}}$ saturation \\
\hline $\mathrm{cm}$ & & & & & & \\
$0-5$ & $0.74 * *$ & $-0.77 * *$ & $-0.75 * *$ & $0.84 * *$ & $0.41 \mathrm{~ns}$ & $0.75 * *$ \\
$5-10$ & $0.82 * *$ & $-0.87 * *$ & $-0.87 * *$ & $0.82 * *$ & $0.39 \mathrm{~ns}$ & $0.83 * *$ \\
$10-20$ & $0.80 * *$ & $-0.80 * *$ & $-0.81 * *$ & $0.80 * *$ & $0.05 \mathrm{~ns}$ & $0.67 * *$ \\
$20-60$ & $0.77 * *$ & $-0.87 * *$ & $-0.86 * *$ & $0.70 * *$ & $0.22 \mathrm{~ns}$ & $0.46 *$ \\
\hline
\end{tabular}

ns: non-significant, *: significant at $P<0.05$, and **: significant at $P<0.01$. 


\section{REFERENCES}

BAYER, C.; MIELNICZUK, J.; AMADO, T.J.C.; MARTIN-NETO, L.; FERNANDES, S.V. Organic matter storage in a sandy clay loam Acrisol affected by tillage and cropping system in southern Brazil. Soil \& Tillage Research, v.54, p.101-109, 2000.

CAIRES, E.F.; FONSECA, A.F.; MENDES, J.; CHUEIRI, W.A.; MADRUGA, E.F. Produção de milho, trigo e soja em função das alterações das características químicas do solo pela aplicação de calcário e gesso na superfície, em sistema de plantio direto. Revista Brasileira de Ciência do Solo, v.23, p.315-327, 1999.

CAIRES, E.F.; BANZATTO, D.A.; FONSECA, A.F. Calagem na superfície em sistema plantio direto. Revista Brasileira de Ciência do Solo, v.24, p.161-169, 2000.

CAIRES, E.F.; FONSECA, A.F.; FELDHAUS, I.C.; BLUM, J. Crescimento radicular e nutrição da soja cultivada no sistema plantio direto em resposta ao calcário e gesso na superfície. Revista Brasileira de Ciência do Solo, v.25, p.1029-1040, 2001.

CAIRES, E.F.; FELDHAUS, I.C.; BARTH, G.; GARBUIO, F.J. Lime and gypsum application on the wheat crop. Scientia Agricola, v.59, p.357-364, 2002a.

CAIRES, E.F.; BARTH, G.; GARBUIO, F.J.; KUSMAN, M.T. Correção da acidez do solo, crescimento radicular e nutrição do milho de acordo com a calagem na superfície em sistema plantio direto. Revista Brasileira de Ciência do Solo, v.26, p.10111022, 2002b

CONYERS, M.K.; HEENAN, D.P.; MCGHIE, W.J.; POILE, G.P. Amelioration of acidity with time by limestone under contrasting tillage. Soil \& Tillage Research, v.72, p.85-94, 2003.

COSTA, A.; CAMPOS, L.A.C.; RIEDE, R.R. Reaction of wheat genotypes to soil aluminum differential saturations. Brazilian Archives of Biology and Technology, v.46, p.19-25, 2003.

FRANCHINI, J.C.; MALAVOLTA, E.; MIYAZAWA, M.; PAVAN, M.A. Alterações químicas em solos ácidos após a aplicação de resíduos vegetais. Revista Brasileira de Ciência do Solo, v.23, p.533-542, 1999.

GASCHO, G.J.; PARKER, M.B. Long-term liming effects on Coastal Plain soils and crops. Agronomy Journal, v.93, p.1305-1315, 2001.

INSTITUTO AGRONÔMICO DO PARANÁ - IAPAR. Informações técnicas para as culturas do trigo e triticale no Paraná - 2003. Londrina, 2003. 202p. (Circular, 126).

MIYAZAWA, M.; PAVAN, M.A.; CALEGARI, A. Efeito de material vegetal na acidez do solo. Revista Brasileira de Ciência do Solo, v.17, p.411- 416, 1993.

MUZILLI, O.; SANTOS, D.; PALHANO, J.B.; MANETTI FILHO, J.; LANTMANN, A.F.; GARCIA, A.; CATANEO, A. Tolerância de cultivares de soja e de trigo a acidez do solo. Revista Brasileira de Ciência do Solo, v.2, p.34-40, 1978.

OLIVEIRA, E.L.; PAVAN, M.A. Control of soil acidity in notillage system for soybean production. Soil \& Tillage Research, v.38, p.47-57, 1996.

PAVAN, M.A.; BINGHAM, F.T.; PRATT, P.F. Toxicity of aluminum to coffee in Ultisols and Oxisols amended with $\mathrm{CaCO}_{3}$ and $\mathrm{CaSO}_{4}$. Soil Science Society of America Journal, v.46, p.12011207, 1982.
PAVAN, M.A.; BLOCH, M.F.; ZEMPULSKI, H.C.; MIYAZAWA, M.; ZOOCLER, D.C. Manual de análise química do solo e controle de qualidade. Londrina: IAPAR, 1992. 38p. (Circular, 76).

PIRES, F.R.; SOUZA, C.M.; QUEIROZ, D.M.; MIRANDA, G.V.; GALVÃO, J.C.C. Alteração de atributos químicos do solo e estado nutricional e características agronômicas de plantas de milho, considerando as modalidades de calagem em plantio direto. Revista Brasileira de Ciência do Solo, v.27, p.121-131, 2003.

PÖTTKER, D.; BEN, J. R. Calagem para uma rotação de culturas no sistema plantio direto. Revista Brasileira de Ciência do Solo, v.22, p.675-684, 1998.

RHEINHEIMER, D.S.; SANTOS, E.J.S.; KAMINSKI, J.; XAVIER, FM. Aplicação superficial de calcário no sistema plantio direto consolidado em solo arenoso. Ciência Rural, v.30, p.263268, 2000.

RHOTON, F.E. Influence of time on soil response to no-till practices. Soil Science Society of America Journal, v.64, p.700-709, 2000.

RITCHEY, K.D.; SILVA, S.E.; COSTA, V.F. Calcium deficiency in clayey B horizons of savannah Oxisols. Soil Science, v.133, p.378-382, 1982.

ROSOLEM, C.A.; FURLANI JR., E.; BICUDO, S.J.; MOURA, E.G.; BULHÕES, L.H. Preparo do solo e sistema radicular de trigo. Revista Brasileira de Ciência do Solo, v.16, p.115-120, 1992.

SALET, R.L.; ANGHINONI, I.; KOCHHANN, R.A. Atividade do alumínio na solução de solo do sistema plantio direto. Revista Científica Unicruz, v.1, p.9-13, 1999.

SCHENK, M.K.; BARBER, S.A. Root characteristics of corn genotypes as related to P uptake. Agronomy Journal, v.71, p.921-924, 1979.

SUMNER, M.E.; SHAHANDEH, H.; BOUTON, J.; HAMMEL, J. Amelioration of an acid soil profile through deep liming and surface application of gypsum. Soil Science Society of America Journal, v.50, p.1254-1258, 1986.

TANG, C.; RENGEL, Z.; ABRECHT, D.; TENNANT, D. Aluminium-tolerant wheat uses more water and yields higher than aluminium-sensitive one on a sandy soil with subsurface acidity. Field Crops Research, v.78, p.93-103, 2002.

TANG, C.; RENGEL, Z.; DIATLOFF, E.; GAZEY, C. Responses of wheat and barley to liming on a sandy soil with subsoil acidity. Field Crops Research, v.80, p.235-244, 2003.

TENNANT, D. A test of a modified line intersect method of estimating root length. Journal of Ecology, v.63, p.995-1001, 1975.

TISSI, J.A.; CAIRES, E.F.; PAULETTI, V. Efeitos da calagem em semeadura direta de milho. Bragantia, v.63, p.405-413, 2004.

WINKLER, H.; SFREDO, G.J. Produção de grãos de trigo e alterações de propriedades químicas ante a calagem em solos de Santa Catarina. Pesquisa Agropecuária Brasileira, v.26, p.105112, 1991.

Received April 07, 2006

Accepted July 17, 2006 